\title{
Investigation of the Health Significance of 4th Grade Students in Physical Education and Sport Department
}

\author{
Aykut DÜNDAR ${ }^{1}$ \\ Mustafa KOÇ æ \\ Adyaman University, School of Physical Education and Sports, Advyaman, Turkey \\ ${ }^{2}$ Email: adundar@adivaman.edu.tr \\ 'Email:mkoccc@gmail.com
}

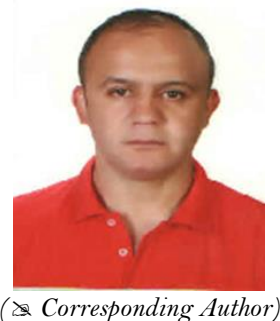

( Corresponding Author)

\begin{abstract}
The knowledge, vision, understanding and practices of a community about health and disease issues show the socio-economic structure, educational and cultural level of that society. Human health is under the influence of the hazards which are the product of various demographic, economic, social, cultural, psychological, physical, chemical and biological factors. For many years health was defined as the absence of the disease. But in recent years it has been recognized as a concept in which health is included in a physical, emotional and mental well-being. The relationship between health and wellness is obvious. Well being can be defined as reaching the level of physical and psychological health which is provided consciously and willingly. For this reason, health is a progress made towards improved health. We call the health condition in which cure and rehabilitation are needed as negative health; the health condition in which there is no illness and which is balanced as neutral health; health condition which is about health conducts improving life quality as positive health. The main purpose of this study is to expose perceptions of students of Department of Physical Education and Sports 4th grade about "health" concept by the means of metaphors. The participants for this study included 43 students from High school of Physical Education and Sports both located in Adiyaman. To collect the study data, each participant was asked to complete the prompt "health is like ... because ..." The content analysis technique was used to analyse study data. According to the results, all of the students (100\%) have developed positive metaphors.
\end{abstract}

Keywords: Metaphor, Health, Student.

Citation | Aykut DÜNDAR; Mustafa KOÇ (2018). Investigation of the Health Significance of 4th Grade Students in Physical Education and Sport Department. Asian Journal of Education and Training, 4(3): 228-232.

History:

Received: 25 May 2018

Revised: 21 June 2018

Accepted: 2 July 2018

Published: 12 July 2018

Licensed: This work is licensed under a Creative Commons Attribution 3.0 License $(\mathrm{cc})$ E

Publisher:Asian Online Journal Publishing Group
Contribution/Acknowledgement: Both authors contributed to the conception and design of the study.

Funding: This study received no specific financial support

Competing Interests: The authors declare that they have no conflict of interests.

Transparency: The authors confirm that the manuscript is an honest, accurate, and transparent account of the study was reported; that no vital features of the study have been omitted; and that any discrepancies from the study as planned have been explained.

Ethical: This study follows all ethical practices during writing.

\section{Contents}

1. Introduction

References. 


\section{Introduction}

World Health Organisation (WHO) defines health as "the state of not only having a disease or disability but also the state of bodily, psychological and social wellbeing”. According to WHO, there are three basic criteria of health:

1- Bodily wellbeing: The state of not having such things as deficiency and malfunction in the texture and organs constituting the body, or not carrying germ.

2- Psychological wellbeing: The state of being able to think consistently with one's age, being able to state what one thinks clearly, being able to understand others, being able to know when to be happy or sad, being able to struggle with hardship, being able to act according to conditions, being happy with achievement and accepting failure, and being at peace with oneself.

3- Social wellbeing: The state of being able to know where to act and how to act, being aware of one's responsibilities, being affectionate to people of older and younger age and having good relations with them, and being friendly to the environment (World Health Organization, 2016).

Perceptions of health indicate the extent to which one is psychologically open to display protective behaviours (Baltaş, 2000).

The way individuals define health and what behaviours they associate with being healthy are influential in whether or not they lead a healthy life. Therefore, knowing the health behaviours and health beliefs of a community is important and essential in delivering healthcare services and in directing health education and health policies. Individuals' perceptions of health can be investigated within the framework of the concept of "social representation" (Moscovici, 1988).

Metaphor is the transfer of meaning from one thing into another thing. The word metaphor was derived from Greek word metapherein (which meant 'to transfer'); and it was formed by combining the words meta (=between), pherein (=to transfer) (Nikitina and Furuoka, 2008). Mish defines a metaphor as "a figure of speech in which a word or phrase expressing an object or an idea literally replaces a word or phrase having similarity or analogy with it" (cited in Groth and Bergner (2005)). Although metaphors are traditionally seen as figures ornamenting a speaker's use of language, psychologists and linguists describe them in a different way. Kramsch, for instance, considers a metaphor as "the mutual transfers between two sources which are often inconsistent" while Orthony and Fainsilber see it as "an important instrument of cognition and communication" (Cited in Nikitina and Furuoka (2008)). Those definitions make metaphors one of the most powerful mental instruments configuring, orienting and controlling our thoughts about the formation and functioning of events (Saban, 2004) another important property of metaphors is that they help humans' cognitive process (Nikitina and Furuoka, 2008). Therefore, metaphors are remarkable as a strong mechanism for mental mapping and modelling for individuals to understand and configure their own world (Arslan and Ve Bayrakçı, 2006).

According to Goldstein, metaphors can be used to re-describe the reality and to re-conceptualise problematic situations since metaphors influence situations and the way we perceive events (Cited in Cerit (2008)). Boostrom states that using a metaphor for teaching does not necessarily mean actualising teaching in the way the metaphor predicts it, but it means thinking teaching as a discussion (Cited in Saban (2004)). In this context, describing the concept of health through metaphors can help to understand the concept better.

\subsection{Purpose}

This study mainly aims to reveal the perceptions of fourth year students of Physical Education and Sport department in relation to the concept of "health" through metaphors. It seeks answers to the following questions in accordance with this purpose:

1. Through what metaphors do the fourth year students of Physical Education and Sport department describe their perceptions of the concept of "health"?

2. What categories can the students' metaphors about the concept of "health" be divided into?

\section{Method}

This study uses qualitative research method and the data collected were put to content analysis. According to Krippendorf, "content analysis is a scientific research method used to be able to make meaningful and valid inferences about texts and contexts in which they are used" (Cited in Gürel and Alem (2010)).

\subsection{Study Group}

The study group was composed of 43 individuals who were the fourth year university students in the school of Physical Education and Sport in Adiyaman University located in the central district of Adiyaman in 2017-2018 academic year. The distribution of the participants in the study group according to gender was as in the following:

Table-1. Distribution of the Participants in the Study Group according to Gender

\begin{tabular}{l|l|l}
\hline GENDER & $(\mathbf{F})$ & $(\mathbf{\%})$ \\
\hline Male & 22 & 51.16 \\
\hline Female & 21 & 48.84 \\
\hline TOTAL & 43 & 100 \\
\hline
\end{tabular}

\subsection{Data Collection}

43 participants who were the fourth year students of the School of Physical Education and Sport in Adiyaman University in 2017-2018 academic year were asked to complete the sentence "Health is like .... because...." . in this way metaphors about the concept of "health", and then the metaphors were divided into categories and students' perceptions of "health" were determined. 


\subsection{Data Analysis}

The article "Mental Images Primary Education First Stage Teachers and Students Have in Relation to the Concept of Knowledge" by Saban (2004) was used in analysing and interpreting the data collected in the research. Accordingly, the metaphors developed by the students of the school of physical education and sport (SPES) were analysed and interpreted at four stages: 1. Naming, 2. Elimination and purification, 3. Compiling and categorising, and 4 . Validity and reliability analyses.

The metaphors developed were put into a temporary list and ordered alphabetically, and it was checked whether or not students used a metaphor clearly at the stage of naming. The metaphors created by the students were re-examined at the stage of elimination and purification and 12 forms having no sources of metaphor and having no explanations were eliminated; thus valid metaphors obtained.

At the stage of compiling and categorising, the metaphors developed were divided into two categories as positive and negative, and then they were divided into 6 categories according to the properties they had in common about the concept of "health". Students' explanations were also given with the metaphors developed.

At the stage of validity and reliability analyses, expert opinion was consulted so as to determine whether or not the metaphors listed in 6 categories were representative of the categories. Two experts were given the following two lists for this:

1. The alphabetical list of 43 metaphors developed by the fourth year students of SPES;

2. The list of 6 categories distinguished by the researcher and the properties of the categories

\section{Findings}

The metaphors created by fourth year students of SPES in relation to the concept of "health" are tabulated and the tables are analysed and interpreted under sub-headings.

\section{Metaphors recommended by the fourth year students of SPES in relation to the concept of "health"}

Under this heading, the metaphors developed by the students are listed alphabetically and the number of students and percentages for each metaphor are given.

The perceptions of $4^{\text {th }}$ year students of the school of physical education and sport in relation to the concept of "health"

\begin{tabular}{|c|c|c|c|c|c|c|c|}
\hline Codes & Metaphors & (f) & $(\%)$ & Codes & Metaphors & (f) & $(\%)$ \\
\hline 1 & Friend & 2 & 4.65 & 13 & Happiness & 4 & 9.30 \\
\hline 2 & Love & 1 & 2.33 & 14 & Banana peel & 1 & 2.33 \\
\hline 3 & Lesson & 1 & 2.33 & 15 & Breath & 2 & 4.65 \\
\hline 4 & Apple & 1 & 2.325 & 16 & Strong body & 1 & 2.33 \\
\hline 5 & Life & 7 & 16.28 & 17 & Fortune & 1 & 2.33 \\
\hline 6 & Determiner of life & 2 & 4.65 & 18 & A new car & 1 & 2.33 \\
\hline 7 & Heart of life & 1 & 2.33 & 19 & Sport & 1 & 2.33 \\
\hline 8 & Peace & 2 & 4.65 & 20 & Water & 1 & 2.33 \\
\hline 9 & Light & 1 & 2.33 & 21 & Tailor & 1 & 2.33 \\
\hline 10 & Building & 1 & 2.33 & 22 & Law & 1 & 2.33 \\
\hline 11 & Reading a book & 1 & 2.33 & 23 & Living & 6 & 13.95 \\
\hline 12 & Fruit & 2 & 4.65 & 24 & Road & 1 & 2.33 \\
\hline \multicolumn{6}{|l|}{ Total } & 43 & 100 \\
\hline
\end{tabular}

As is clear from Table 2, the fourth year students developed 24 metaphors about the concept of health. It was seen that the meaning universe of the metaphors was very close, and thus it may be inferred from this that students have similar worlds of images. All (100\%) of the metaphors developed were positive and the students' attitudes towards the concept of health were also positive. Accordingly, it was found that the participants had used the metaphors of life, happiness and living most frequently. It was also remarkable that those metaphors were abstract concepts. It may be concluded based on these metaphors that students' world of meanings was configured by abstract metaphors. In addition to that, students also developed concrete metaphors such as fruit and friend about the concept of health.

\subsection{Categories of Metaphors Students Use about the Concept of Health}

Metaphors developed by the students were divided into categories, and the number of students and percentages for each metaphor were given under this heading.

On examining the metaphors developed about the concept of health, it was found that more than half (65.1\%) of the students considered health as a pre-requisite, and that it was a must for human prosperity. Thus, the metaphors such as the determiner of life, living, fortune, peace, heat of life, etc. also referred to the parallel concepts of a peaceful life. Besides, such metaphors as light, lesson, reading a book, love, breath and happiness referred to the integrated relations between health, achievement and soul.

$9.3 \%$ of the students stated that health was an instrument for the maintenance of knowledge through such metaphors as tailor, friend, living and building; $9.3 \%$ referred to the associations between health and time by using metaphors such as apple, fruit and new car; $4.6 \%$ referred to the mental side of health with metaphors of sport and law; $6.9 \%$ referred to the regularity aspect of health with metaphors such as friend, road and living and $4.6 \%$ referred to the physiological side of health with such metaphors as strong body and water. As is clear from Table 3, metaphors such as living and happiness are included in differing categories. This situation is associated with the framework of meanings assigned to the metaphors. 
Table-3. Positive Metaphors Developed by Students about the Concept of Health, and the number of Students and Percentages for those Metaphors

\begin{tabular}{|c|c|c|c|c|c|c|c|}
\hline \multirow{3}{*}{ 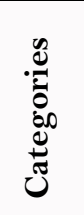 } & \multirow{3}{*}{ Codes } & \multirow{3}{*}{ Metaphors } & \multirow{3}{*}{ Sample student explanations } & \multicolumn{4}{|c|}{$\begin{array}{l}\text { Students representing the } \\
\text { metaphors }\end{array}$} \\
\hline & & & & \multirow[b]{2}{*}{ (f) } & \multirow[b]{2}{*}{ (\%) } & \multicolumn{2}{|c|}{ Codes total } \\
\hline & & & & & & $(\mathbf{f})$ & $(\%)$ \\
\hline \multirow{13}{*}{ 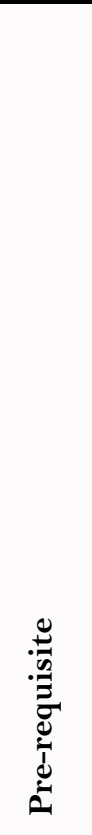 } & 6 & Determiner of life & $\begin{array}{l}\text { "If you are healthy, you can do anything you } \\
\text { like in life. It is a pre-requisite." }\end{array}$ & 2 & 4.65 & \multirow{13}{*}{28} & \multirow{13}{*}{65.1} \\
\hline & 23 & Living & "Without health life has no meaning." & 4 & 9.30 & & \\
\hline & 14 & Banana peel & $\begin{array}{l}\text { "If you can keep pace with it, you live long. If } \\
\text { you step on the banana peel, your life will } \\
\text { slip." }\end{array}$ & 1 & 2.33 & & \\
\hline & 17 & Fortune & "If there is no health, there is nothing in life." & 1 & 2.33 & & \\
\hline & 8 & Peace & $\begin{array}{l}\text { "A healthy life enables us to lead a peaceful } \\
\text { life." }\end{array}$ & 2 & 4.65 & & \\
\hline & 9 & Light & "Health is the light in our life." & 1 & 2.33 & & \\
\hline & 5 & Life & "Health is necessary to cling to life." & 7 & 16.28 & & \\
\hline & 3 & Lesson & $\begin{array}{l}\text { "If it is good, it is good; if it is bad, there is no } \\
\text { peace. }\end{array}$ & 1 & 2.33 & & \\
\hline & 11 & Reading a book & $\begin{array}{l}\text { "Healthy individuals can enjoy life more and } \\
\text { can look at events positively." }\end{array}$ & 1 & 2.33 & & \\
\hline & 7 & Heart of life & $\begin{array}{l}\text { "there is no meaning in life lived without } \\
\text { health." }\end{array}$ & 1 & 2.33 & & \\
\hline & 2 & Love & $\begin{array}{l}\text { "we cannot enjoy any moments of life unless } \\
\text { there is health." }\end{array}$ & 1 & 2.33 & & \\
\hline & 15 & Breath & "We cannot live without breath." & 2 & 4.65 & & \\
\hline & 13 & Happiness & "Happy individuals always feel good." & 4 & 9.30 & & \\
\hline \multirow{4}{*}{ 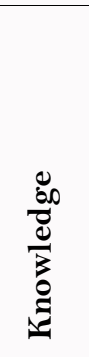 } & 21 & Tailor & $\begin{array}{l}\text { "Someone who knows the rules of health can } \\
\text { improve his health just as a tailor can sew the } \\
\text { rips in a piece of cloth". }\end{array}$ & 1 & 2.33 & \multirow{4}{*}{4} & \multirow{4}{*}{9.3} \\
\hline & 1 & Friend & $\begin{array}{l}\text { "it treats you just as you treat it. } \\
\text { You will take care with your health." }\end{array}$ & 1 & 2.33 & & \\
\hline & 23 & Living & $\begin{array}{l}\text { "it gets into a shape according to the criteria } \\
\text { humans set in their life." }\end{array}$ & 1 & 2.33 & & \\
\hline & 10 & Building & $\begin{array}{l}\text { "you construct a strong building if you work } \\
\text { with a good constructor." }\end{array}$ & 1 & 2.33 & & \\
\hline \multirow{3}{*}{$\stackrel{\mathscr{E}}{\mathscr{E}}$} & 4 & Apple & $\begin{array}{l}\text { "Just as an apple goes rotten through time, } \\
\text { our health also disappears through time." }\end{array}$ & 1 & 2.33 & \multirow{3}{*}{4} & \multirow{3}{*}{9.3} \\
\hline & 12 & Fruit & "it becomes mouldy fruit when it is time." & 2 & 4.65 & & \\
\hline & 18 & A new car & "A car breaks down through time." & 1 & 2.33 & & \\
\hline \multirow{2}{*}{ : } & 19 & Sport & $\begin{array}{l}\text { "It returns you if you care for it and if you } \\
\text { consider it important." }\end{array}$ & 1 & 2.33 & \multirow[t]{2}{*}{2} & \multirow[t]{2}{*}{4.6} \\
\hline & 22 & Law & $\begin{array}{l}\text { "we should care our health just as we should } \\
\text { care laws." }\end{array}$ & 1 & 2.33 & & \\
\hline \multirow{3}{*}{ 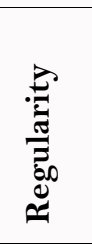 } & 1 & Friend & $\begin{array}{l}\text { "1t provides someone with self-confidence and } \\
\text { organises his life." }\end{array}$ & 1 & 2.33 & \multirow{3}{*}{3} & \multirow{3}{*}{6.9} \\
\hline & 24 & Road & $\begin{array}{l}\text { "The more regular a road is, the easier the } \\
\text { distance is to go". }\end{array}$ & 1 & 2.33 & & \\
\hline & 23 & Living & $\begin{array}{l}\text { "It assures that one can take on a role in } \\
\text { society." }\end{array}$ & 1 & 2.33 & & \\
\hline \multirow{2}{*}{ 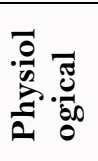 } & 16 & Strong body & $\begin{array}{l}\text { "Healthy life increases the resistance of body } \\
\text { through sport." }\end{array}$ & 1 & 2.33 & \multirow{2}{*}{2} & \multirow{2}{*}{4.6} \\
\hline & 20 & Water & $\begin{array}{l}\text { "Water is of vital importance. The majority of } \\
\text { human body is composed of water." }\end{array}$ & 1 & 2.33 & & \\
\hline
\end{tabular}

Source: results from frequency and percentage distribution

This study considered the references made in students' statements while classifying thematically the metaphors they had developed for the concept of health. In this context, themes such as time, physiology, attention and regularity were distinguished by taking the integrity of physical health and psychological health into consideration.

The fact that the metaphors developed in relation to health were generally positive and made references to the future made us think that the ages of the students in the study group were influential in this. Besides, considering the fact that the study group was young in general, this could be associated with the fact that the metaphors were not uniform and not very striking.

\section{Discussion and Conclusion}

It is apparent from literature review that metaphoric investigations have been done in Turkey in the field of social sciences. Aydin and Ve Ünaldı (2010); Ibret and Aydınözü (2011); Akkaya (2011); Güven (2015) and Gün (2015) are a few of the one performed in recent years. The studies mentioned are generally concerned with a wide range of phenomena or concepts such as language, culture, education and foreigners' perceptions of speaking in Turkish.

On examining similar studies in the literature, it was found that Açısöz et al. (2013) in their study entitled "Analysing the Correlations between Nursing Students' perceptions of Health and their Behaviours of Health 
Development", investigated the correlations between nursing students' perceptions of health and their behaviours of health development and concluded that students perceived their health very well.

With their study entitled "Correlations between University Students' Perceptions of Health and their Behaviours of Healthy Lifestyle", Tuğut and Bekar (2008) on the other hand, conducted a sectional study to determine the correlations between Cumhuriyet University students' perceptions of health and their behaviours of healthy lifestyle, and the researchers concluded that the students had positive perceptions of health.

Considering the categories for the concept of health, it was found in this study that the participants used the category of "pre-requisite" most and that they developed the metaphor of "health is necessary to cling to life" most frequently. Therefore, it may be stated that health plays an important role for students to maintain their life.

Sevinç et al. (2014) in their study entitled "The Effects of 8-week Step-Aerobics Exercise (situational and Continuous) on Women's Levels of Anxiety and on their Life Quality", investigated the life quality levels of women who had done step-aerobics exercise regularly for 8 weeks and the life quality levels of women who did not do any sports, and thus they found that sport had positive effects on women's life quality.

This study found that the fourth year students of physical education and sport department had rather positive perceptions about the concept of "health" and that they mostly demonstrated this through abstract metaphors. It is thought - on the basis of metaphoric expressions that had been divided into themes such as time, perception, regularity and mental processes - that the areas of association are generally positive.

Thus, one of the most important conditions to be healthy is to do sport. Therefore, sports activities can be diversified and made widespread so as to raise the life quality of the students of physical education and sport department at university.

Considering the metaphoric perceptions of students with whom the research was conducted, it was found that the concepts of sport, life, peace, physiological health and psychological health were assessed in a holistic manner. Thus, it may be said that students' fields of association about the concept of health are versatile.

This study scanned students' schemata of associations about health metaphorically. In consequence, it was found that the majority of metaphors about health were positive. Students' metaphoric perceptions about health had integrity on the axis of mental processes and physiological and psychological health. Accordingly, another finding was that students did not consider health as unidimensional.

\section{References}

Açıksöz, S., Ş. Uzun and F. Arslan, 2013. Relationship between perceptions of health status and health promotion behaviors in nursing students. Gülhane Medical Journal, 3(55): 181-187. View at Google Scholar | View at Publisher

Akkaya, A., 2011. Perceptions of 8th grade elemantry students about speaking concept. Adiyaman University Journal of Social Sciences, $11(7): 1-9$

Arslan, M.M. and M. Ve Bayrakçı, 2006. Investigation of metaphorical thinking and learning approach in terms of education. National Education Journal, 35(171): 100-108.

Aydin, F. and Ü.E. Ve Ünald,, 2010. The analysis of geography teacher candidates' perceptions towards "geography" concept with the help of metaphors. International Online Journal of Educational Sciences, 2(2): 600-622. View at Google Scholar

Baltaş, Z., 2000. Health psychology. İstanbul: Remzi Bookstore.

Cerit, Y., 2008. Students, teachers and administrators' views on metaphors with respect to the concept of teacher. Jounal of Turkish Educational Scinces, 6(4): 693-712. View at Google Scholar

Groth, R.E. and J.A. Bergner, 2005. Pre-service elementary school teachers' metaphors for the concept of statistical sample. Statistics Education Research Journal, 4(2): 27-42. View at Google Scholar $\mid$ View at Publisher

Gün, M., 2015. Turkish teachers and Turkish teaching department students' perceptions regarding foreigners' speaking Turkish. Researcher Social Science Studies, 3(1): 87-101.

Gürel, E. and J. Alem, 2010. A content analysis of a post modern animated sitcom: The simpsons. Journal of International Social Research, 3(10): 332-347. View at Google Scholar

Güven, M., 2015. From thought to language: Metaphors in Oruc Aruoba. Journal of Language and Literature, 3(13): 44-51. View at Google Scholar

Ibret, B.ய̈. and D. Aydınözü, 2011. The metaphors developed by elementary school-second stage students on the concept of world. Kastamonu Education Journal, 19(1): 85- 102. View at Google Scholar

Moscovici, M., 1988. Notes towards a description of social representations. European Journal of Social Psychology, 18(3): 21 1-250. View at Google Scholar | View at Publisher

Nikitina, L. and F. Furuoka, 2008. A language teacher is like...": Examining Malaysian students' perceptions of language teachers through metaphor analysis. Online Submission, 5(2): 192-205. View at Google Scholar

Saban, A., 2004. Entry level prospective classroom teachers' metaphors about the concept of teacher. Journal of Turkish Educational Sciences, 2(2): 131-155.

Sevinç, D., N.F. Kishalı and M. Çolak, 2014. The effect of 8-week step-aerobic exercises (Conditional and Continuous) anxiety levels and quality of life on females. 2nd International Physical Education and Sports Congress for the Disabled Abstract Book S.141.

Tuğut, N. and M. Bekar, 2008. Cumhuriyet university student's healthy perception state and the correlation of health promotion life style. Journal of Anatolia Nursing and Health Sciences, 3(11): 17-26. View at Google Scholar

World Health Organization, 2016. Retrieved from http://www.who.int/about/en/. 